considerably thicker. The markings of the body have materially changed. The prothoracic shield, in the two last stages split in two longitudinally, is now also split tranversely, so that it is represented by four transversely narrow piliferous warts. On each succeeding segment there is a transverse dorsal broad black-brown band, which encloses a yellowish white narrow stripe, which in the middle and at each end enlarges into a round spot; there are ten such curious whitish stripes on a blackish ground, which only extend part way down the sides of the body toward the spiracles. The piliferous warts are not so pronounced as in the preceding stages, while the body and hairs are of a pale chestnut hue.

Stage VI and last. - Length 23-24 mm. (Evidently underfed, Mr. Edwards's specimens measuring $5^{2}$ $\mathrm{mm}$.). In the final stage the head is pale chestnut, with no black portion. The top of the body is now black, and each segment except the first behind the head bears two transverse white stripes, one in front and the other behind a transverse chestnut-red band, enclosing the piliferous warts, which are much more prominent than in the 5 th stage. Of the two yellowish white transverse stripes, the one on the front of the segment is divided into a central dot with a separate slash on each side; the hinder band consists of three portions, a central dot, from which a stripe passes each side, and instead of ending in a dot, makes a loop or hook. Our drawings made by $\mathrm{Mr}$. Bridgham agree well with Mr. Edwards's description.

It thus appears that the markings of the two last stages of this larva are very different from those of any genus whose larval history is known to us; Mr. Edwards has pointed out its relations to the larva of Arachnis and Ecpantheria, with which we are not familiar.

\title{
TWO SPECIES OF AESCHNA.
}

By hermanN AUgUSt hagen, CAMBridge, MASs.

I. Aeschna sitchensis. Aeschna sitchensis Hagen, Syn. Neur. N. A. I I9, I.

Blackish-brown, spotted with blue; head yellow in front, anteriorly with a narrow transverse black line; superiorly a large black spot in the shape of a $\mathrm{T}$, nearly or entirely connected each side with a black band before the eyes, forming two yellow spots surrounded with black on the superior part of the front ; rhinarium and border of the labrum black; eyes largely connected; occiput yellow, hind border elevated, black on each side; thorax fuscous, dorsum with two median elongated points; sides 
darker with two maculose narrow, very angular stripes, whitish blue; abdomen long, slender, equal, very much arcuated behind the inflated base in both sexes; brown spotted with blue; segments 3-Io with two large, apical blue spots, 3-7 with two basal blue spots; second segment with two blue lines on each side; appendages ( $\hat{\sigma}$ ) black, moderate, a little incurved, foliaceous, the base narrow, finely denticulated on the inner margin; carinated within, before the apex the carina is inflated and finely spinulose; the rounded apex has a very short, acute, incurved spine ; inferior appendage one-half shorter, elongately triangular, obtuse ; appendages ( $\$$ ) foliaceous, broad (only the basal part is known). Genital parts in the second segment ( $\hat{\sigma}$ ) similar to those of $A$. septentrionalis, but the outer spine of the anterior piece is longer than the hamulus, slender, the tip sharp and curved downwards; hamuli foliaceous, flat, cut straight on the tip; feet brown, black beneath; wings hyaline, costa yellow; pterostigma elongated, fuscous ; membranule brackish gray ; the subnodal sector sometimes not bifurcated; I5-I8 antecubitals, 8-I I postcubitals. Length $55-58 \mathrm{~mm}$. ; alar expanse $7^{8-8} 3 \mathrm{~mm}$.; pterostigma $4 \mathrm{~mm}$.

НАв. Sitka, Alaska; Saskatchewan, Brit. Amer.

I have seen three males and two females. In my Synopsis an imperfect female was described; this species is very similar to $A$. septentrionalis but differs in the genital parts of the male, the longer connections of the eyes, the color of the front, and the slender abdomen. Aeschna minor Rambur, quoted in the Synopsis, p. 2o, as very similar, belongs to $A$. janata Say.

II, Aeschna septentrionalis. Aeschna septentrionalis Burm. Handb., r839, v. 2, 839, I 1.-Hagen Syn. Neur. N. A., I 20, 2.

Blackish-brown, spotted with blue; head yellow in front; anteriorly a nar. row transverse line, superiorly a large spot in the shape of a $\mathrm{T}$; the rhinarium and margin of the labrum black; eyes shortly connected; occiput large, yellowish, the hind border elevated, black on each side; thorax fuscous, dorsum with two median elongated points ; sides darker with two narrow, maculose and angulated stripes, whitish-yellow; feet black, above rufous; abdomen long, stoutish, narrowed behind the inflated base ( $\hat{\delta})$, black, spotted with blue; last segment blue, with a broad black median band, scarcely reaching the tip; an elevated basal tooth above ( $\hat{o})$; appendages brownish black, moderate, a little incurved, foliaceous, the base narrow, a basal obtuse tubercle beneath ; carinated inwardly, apex obtuse inflated in front; inferior appendage one half shorter, elongately triangular, obtuse ; genital parts in the second segment (f) with the anterior piece elevated; strongly depressed in the middle, with a conical, straight, stout spine, as long as the hamulus on each side ; hamuli foliaceous, cut obliquely on the tip with the outer angle rounded, the interior part is bent up suddenly, large, triangularly shaped on the base; penis with a hook on 
the antepenultimate segment; appendages ( $\$$ ) short $(3 \mathrm{~mm}$.) foliaceous, broad, obtuse, wings hyaline, costa yellow; pterostigma elongated, fuscous; membranule blackish gray; the subnodal sector sometimes not bifurcated; 13-16 and 18 antecubitals; IO-I 2 postcubitals ; 4-5 areoles beneath the pterostigma. Length 5 I-6o mm.; alar expanse 74-86 $\mathrm{mm}$.; pterostigma $4 \mathrm{~mm}$.

HAB. Labrador; Fort Resolution and Saskatchewan, Brit. Amer.; one of White Mountains, N. H.

This species is very much like $A$. borealis from Europe; I am not able to separate the males, except that the $T$ spot on the front has a larger and more rounded head in $A$. septentrionalis; the appendages of the female are more widely separated at the base, less broad and somewhat incurved in the European species. I consider the two species as local varieties, but owing to the obvious difference in the appendages of the females it seems more prudent to keep them separate for the present. I have compared i5 specimens of A. septentrionalis and 9 specimens of $A$. borealis from Lapland, Sweden, Silesia and Switzerland. Both are arctic species. Many years ago I saw a specimen from the Wilui River, Siberia, but this specimen is not at hand and as at that time I believed $A$. sitchensis to be the same species I am unable now to say if the Siberian specimen belongs to $A$. borealis.

\section{DESCRIPTIONS OF SOME NEW NORTH AMERICAN DOLICHOPODIDAE.}

BY William M. WHEeler, MilWAUKEe, Wis.

(Continued from $p \cdot 343 \cdot$ )

Gymnopternus poenitens, n. sp. $\delta$

Length $2.75 \mathrm{~mm}$.; length of wing $2.75 \mathrm{~mm}$.

Dark metallic green. Face moderately broad, covered with hoary dust. Antennae black throughout, third joint large and of the usual shape, somewhat pointed and covered with conspicuous whitish pubescence; pubescence of the arista, which is inserted in the middle of the dorsal contour of the third joint, appressed and perceptible only with difficulty. Front rather dull metallic green; cilia of the in- ferior orbit white. Thoracic dorsum shining blackish green, posteriorly with a brilliant golden reflection, apparently without any traces of dust. Scutellum blackish green with a golden reflection, bearing a few black hairs besides the usual setae. Pleurae anteriorly metallic greenish black, posteriorly black, overlaid with hoary dust. The yellow tegulae have black cilia. Abdomen blackish green, lacking the golden reflection of the thorax and scutellum; venter black, dusted with white; hypo- 

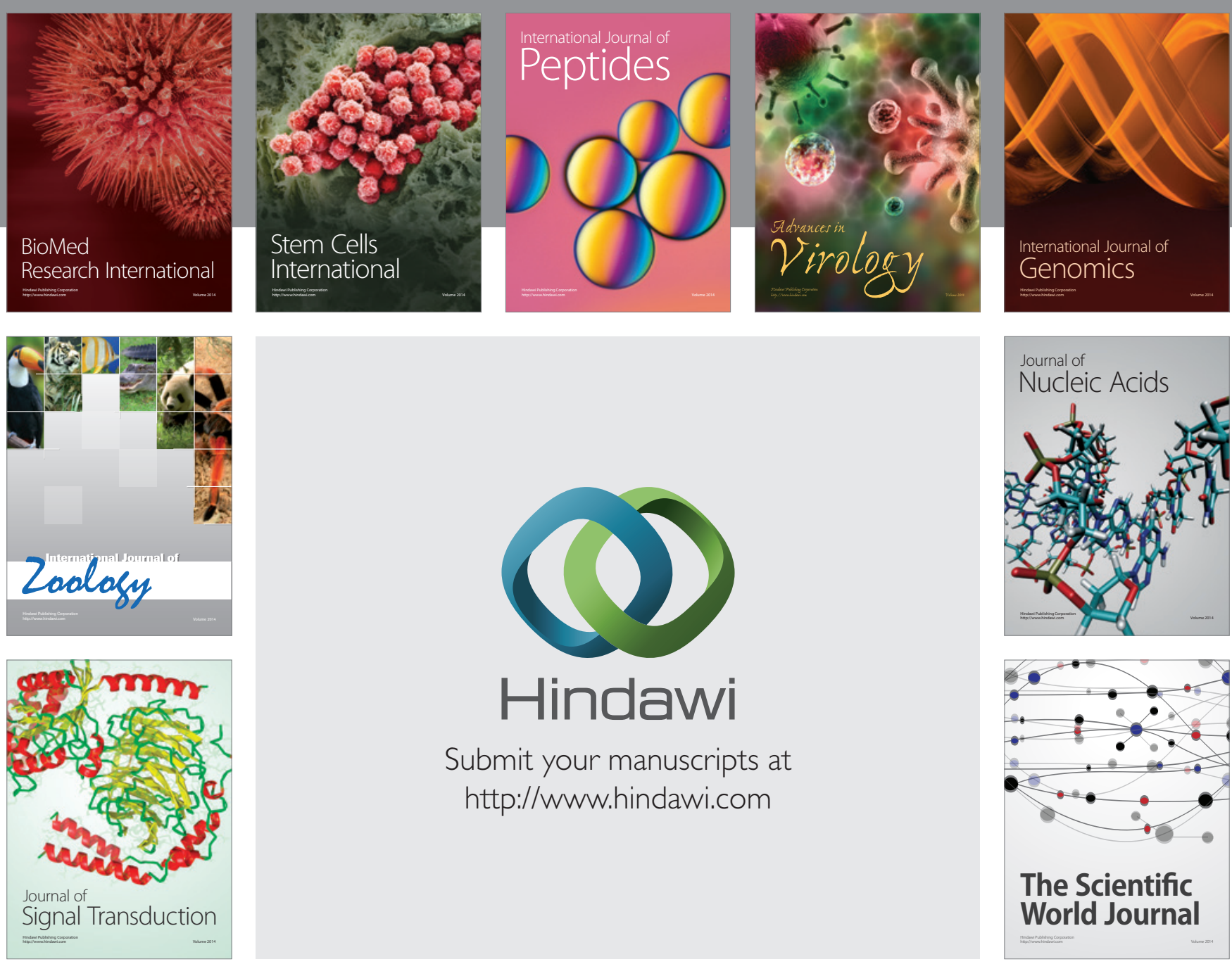

Submit your manuscripts at

http://www.hindawi.com
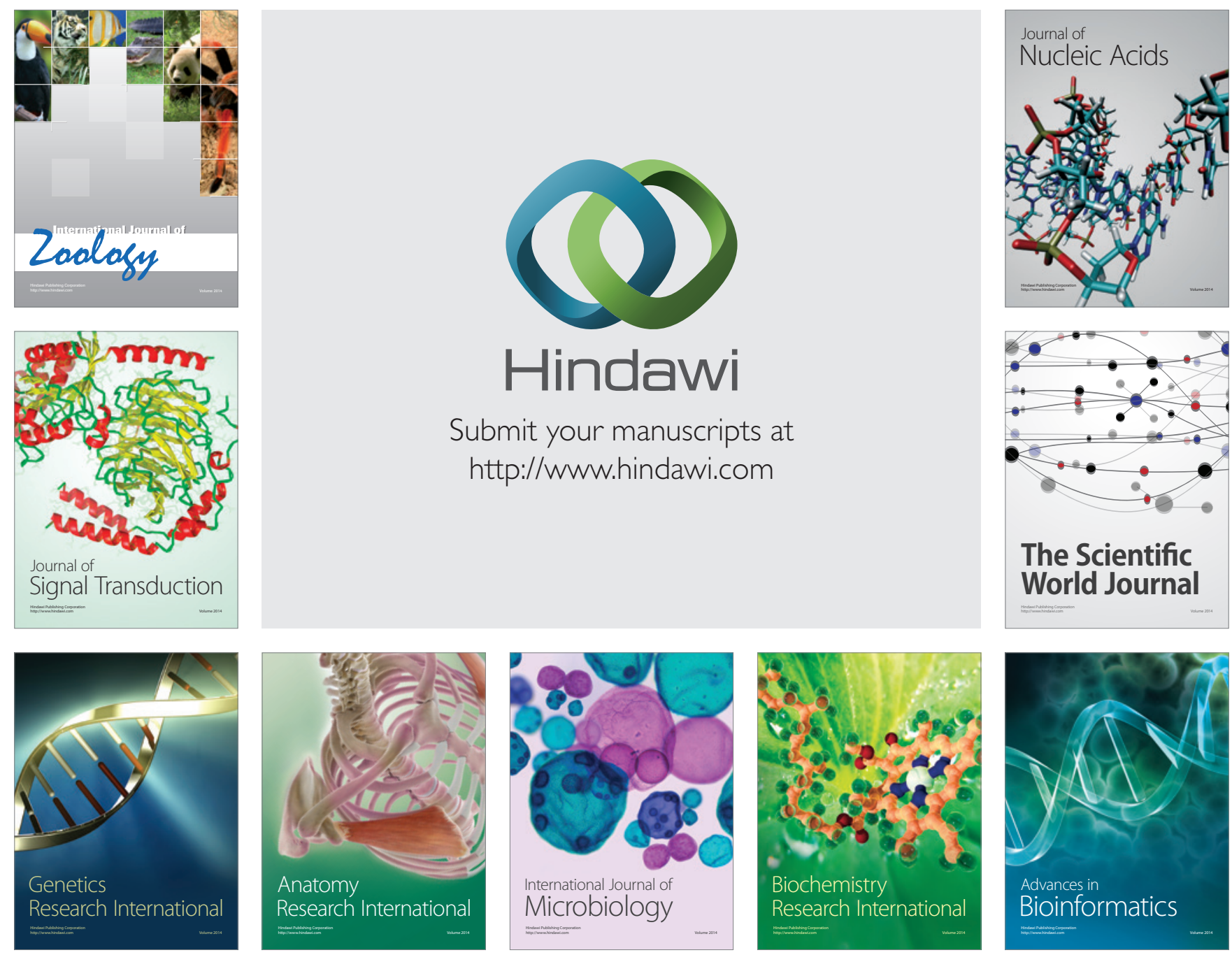

The Scientific World Journal
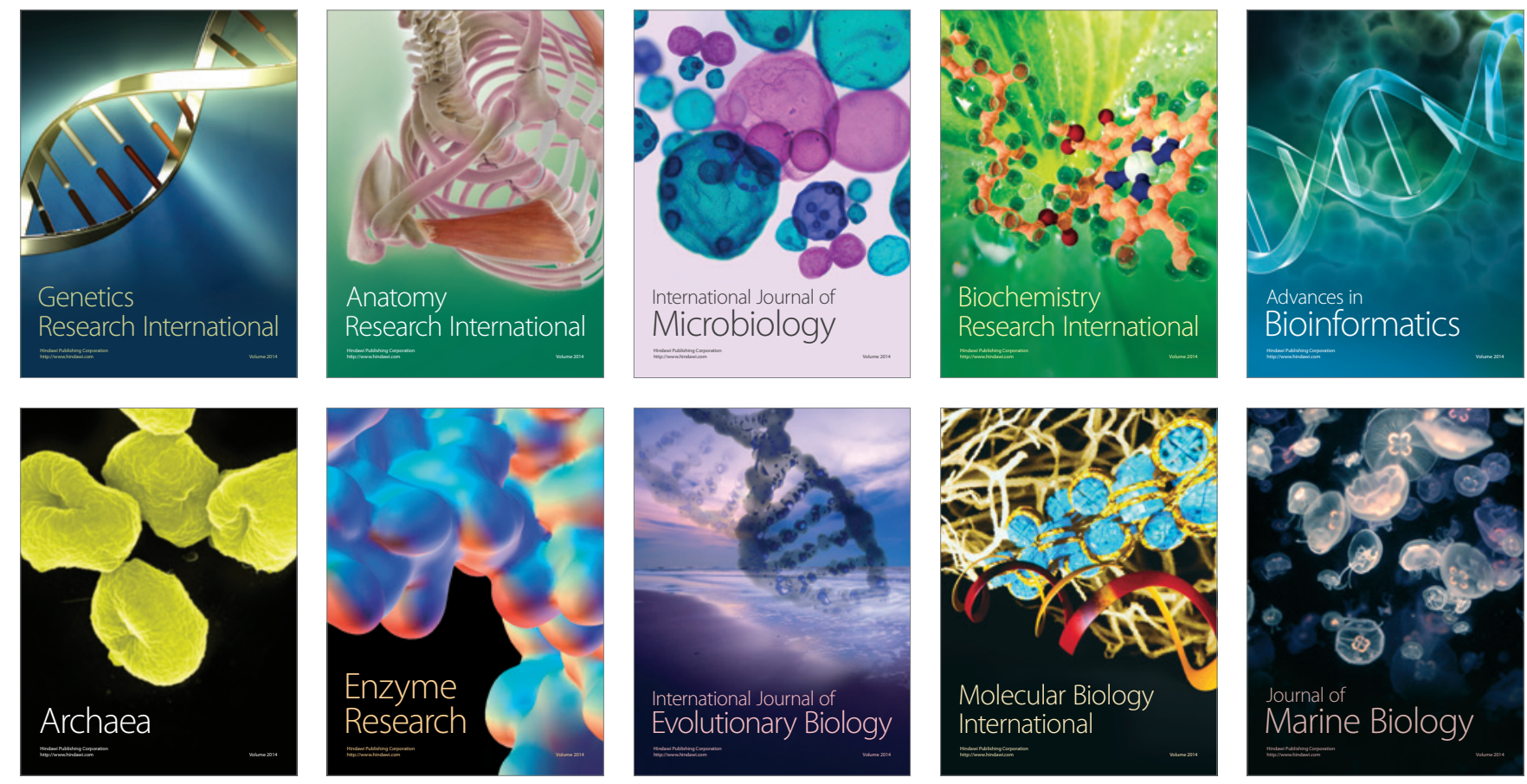